Similarly the initial letters of the lines in the first column of the recto, and the concluding letters of the lines in the second column of the verso are, for the most part, lost to us owing to the manner in which the leaf has been bound into the Codex. Furthermore, the bottom of the leaf has been cut off, causing the loss of the last line of both columns on the recto, and of the second column on the verso. Nevertheless in spite of these and other injuries, it is possible, by making the most of what remains, to obtain a fairly exact notion of the original text. The writing on the recto appears to have been freshened up by retracing, but there is no indication of any departure from the original impressions. The verso has not been dealt with in this way. The leaf now measures $21.6 \times 16.5 \mathrm{cmm}$.

As the representation of the fragment on pp. 87-88 is drawn up for critical as distinct from antiquarian ends, letters which are imperfect in the MS are printed without qualification if the traces that remain, however slight, place the identity of the letter beyond doubt. Letters which are in any degree doubtful, or which can only be certainly determined by inference, are enclosed in brackets. Letters of which no trace remains in the MS are printed in small italic type. When there is some positive reason for questioning the correctness of letters thus supplied, they are enclosed in brackets.

The readings quoted in the notes from $\mathrm{S}$ (Codex Seguierianus), $\mathrm{P}$ (Codex Parisinus 1647 A), W (Codex theol. Wirceburgensis 145 ), M (Codex Monacensis lat. 208), $\mu$ (Codex Monacensis lat. 18203), and the Lambeth MS are based upon my own examination of those MSS.

H. L. RamSay.

\title{
THE GENUINE PROLOGUE TO AMBROSIASTER ON SECOND CORINTHIANS.
}

Even from the critical notes of the Benedictine editors one can see that the manuscript tradition of the Ambrosiaster commentaries is confused to a greater extent than usual at two points. These are, first, the end of the commentary on Romans and the beginning of that on First Corinthians, and, second, the end of the commentary on First Corinthians and the beginning of that on Second Corinthians.

Thus the following colourless production poses in the printed editions as the prologue to the commentary on the Second Epistle to the Corinthians :-

'Secundam epistulam apostolus scribit Corinthiis, cuius haec principalis est causa : quoniam in prima pro quorundam peccatis doctores 
eorum praecipue corripuerat, et multum fuerant contristati, nunc eos consolatur, suum eis proponens exemplum, et docens non debere aegre ferre, quod pro aliorum sunt salute correpti, cum ipse pro aliena salute periculis cottidie et morti subiaceat.'

I now publish what is certainly the genuine prologue, adding a proof of its authenticity from the character of the language. My knowledge of 1 is derived from manuscript collations in the possession of Father Brewer, S.J., of Feldkirch, who is preparing the edition of the commentaries for the Vienna Corpus Scriptorum Ecclesiasticorum Latinorum. Unwilling to take from him the honour of publishing this valuable document, and yet knowing it to be impossible to present my proof of its genuineness apart from its text, I asked, and obtained, his most generous permission to publish this prologue. I here offer him my heartiest thanks.

The document in question is contained in two MSS at least, the MS of Troyes, n. $43^{2}$ (saec. ix-x), and the MS of Koln, n. xxxiv (saec. $x$ ). For other reasons, I should not be surprised to learn that the Troyes MS is the best in existence for the commentaries on First and Second Corinthians. The Koln MS is also of great value. I give the text of the Troyes MS, expanding the contractions.

'Sciens sanctus apostolus profecisse epistolam quam ad arguendam plebem Corinthiorum miserat propter diuersos illorum errores, aliam iterum epistolam ordinat ad exhortandam obauditionem eorum, et tangit horum contumaciam qui emendari ${ }^{1}$ nequiuerant, in hoc tamen animo releuatus quia ea quae ad ecclesiasticam ordinationem pertinent audierat esse correcta, certus deinceps quia et uitia eorum paulatim corrigerentur, praeterea quod ex magna parte coeperant esse obaudientes. Qui ergo ea quae ad fidem et ecclesiasticum ordinem pertinent emendauerant sine dubio spes erat emendandi mores et conuersationem. Ac per hoc festinanter scribit eis ut contristati ex correptione consolationem haberent et cresceret in eis fructus paenitentiae, ut, uidentes iam placere se ei cui displicuerant, promptiores fierent circa bonos actus. Quid est enim paenitere, nisi iam ab errore cessare, interueniente mentis dolore? Ut ergo probet iam bene se de his sentire, sic scribit ad eos.'

I now proceed to illustrate the language of this prologue by parallels derived from the commentaries and the Quaestiones Veteris et Novi Testamenti by the same author. The following passage from quaest. 102 would alone suffice for proof:- Hinc est unde apostolus plebem Corinthiorum arguit, propter quod illum, qui publice uxorem patris habebat, non corriperent aut euitarent, ut se emendarent dicens . . . Ac per hoc quasi consentientes eos crimini eius apostolus arguit' (Migne,

1 Emendare, Colon. 
P. L. xxxv, col. 23 I I, ll. I 3 ff.). Compare tract. in 2 Cor. vii 14 si ii qui arguuntur, incipiant emendare se.

Sciens occurs in this author a very great number of times as the first word in a sentence or clause, with a noun clause dependent on it. It is unnecessary to give examples.

Sanctus apostolus and proficere are also frequent expressions.

For arguendam thus used compare, in addition to the passages above cited :- gentiles arguis quod sine lege et deo sint (in Rom. i1 $2 \mathrm{I}$ ); in istis ergo omnium similium arguitur malum (in Rom. iii 18 ); hic ualde arguit temeritatem illorum (in $\mathrm{I}$ Cor. iii 2 ); in quibus enim tanta uitia arguit ... (in I Cor. iv 8), cet.; arguitur etiam inprobus Manicheus (qu. $76(72))$, cet.

Plebem : 'congregation,' 'church': cf. salutare plebem Romanam ad quam scribit (in Rom. xvi 22); in una plebe duobus populis scribit (in I Cor. i 4); qui prophetat, omnem plebem aedificat (in I Cor. xiv 4); plebis erat corripere eum quem uidebant tam turpiter et obscene inter eos uersari (qu. 102, col. 23II); septem ecclesiae nuncupantur in una plebe (qu. 47); qu. 120.

Diuersus is a favourite word of this author.

Obauditio (cf. Philem. 2 I) : inobauditio occurs in the commentaries (in 2 Cor. vii 7 ), never in the Quaestiones. The form obaudio, though much less common in Latin than oboedio, is the form almost always found in the commentaries (e. g. Migne, P. L. xvii (later issue) col. 143 A, $270 \mathrm{C}, 294 \mathrm{~B}$, $296 \mathrm{D}, 298 \mathrm{~B}$, cet.) : oloedio is the exception (e. g. 248 A, 325 A codd., $534 \mathrm{D})$. On the contrary, obaudio occurs only once in the Quaestiones (qu. 106, col. 2319,67), and in that place one MS reads oboedio. The difference may be after all merely one of scribes. Inoboediens (e.g. $248 \mathrm{~A}$, qu. 70) and inoboedientia (in I Cor. xiii 2) are found in the commentaries.

Tangit 'touches on,' 'refers to': so Migne xvii 188 A, 193 C, cet.; qu. II 1, Ir 3 , I 5 bis, cet.

Emendari: it is somewhat difficult to decide between the passive and the active. Emendo, reformo and corrigo are sometımes used by this author intransitively, like our word 'reform': emendo, e.g. $333 \mathrm{D}$, 353 B bis, qu. 68 ; reformo, qu. I 26 (codd.); corrigo, in I Cor. vi I I, and at least seven other times in comm.; qu. 102 pr.

Animo releuatus: cf. releuatur enim anima patientis (qu. 68); per omnia releuati (qu. 44); in futuro iudicio releuatus, qu. 115 .

Ecclesiasticam ordinationem: cf. ordinis officii ecclesiastici (in I Cor. xi 4 ); salutatio ecclesiastica (in 2 Cor. xiii 11 ) cet. ; ecclesiastica potestas qu. 93 ; ius ecclesiasticum qu. 93 bis; 102 bis, cet.

Certus quia ... corrigerentur: certus quia ... possit occidi (qu. 5); certi quia ... non potest polluere (in I Cor. $\mathrm{x} 28$ ); certi quia ... 
traderent (in 2 Cor. vii 5 ); certus quia obaudirent (in 2 Cor. viii 23 ); certus apostolus quia exitia . . . ministrantur (in Eph. vi I I) ; certi quia ... habentur (in 2 Tim. iii 12 ) ; certus uanitatem uulgi mortuos magis ut deos uenerari quam uiuos (qu. 25); certus dei uoluntatem non debere ab homine retractari (qu. Iog, col. 2326); qu. I I5 et saep.; cf. also ignari quia non licuit (qu. 46, col. 2245); certum est ergo quia non ascendit (qu. $74(78)$ ).

Ex magna parte: ex magna parte, ex parte, ex aliqua parte, cet. are frequent.

Sine dubio is used by the author almost to the exclusion of procul dubio. Examples are $5 \mathrm{I} \mathrm{C,} 78 \mathrm{~A}, 84 \mathrm{D}, \mathrm{I} 55 \mathrm{~B}$, I96 C, $200 \mathrm{C}$, cet.; qu. 3, 30, 40, 46, 5I, 62, 76, 81, 83, cet. Procul dubio occurs e.g. 195 C; qu. 102.

Ac per hoc is found scores of times in each work.

Festinanter: e.g. qu. Iog (col. 2326, 1. 27 ).

Fructus paenitentiae: sine fructu paenitentiae (in Rom. ii 4 ); fructus erit agentibus paenitentiam qu. 102 (col. 2304, 20); itaque et est fructus paenitentiae, ibid. (1. 25); ut hac tergiuersatione fructum amputet paenitentiae, ibid. (1. 5I) ; fructus aliquis paenitentiae, ibid. (1. 54); quis autem fructus est paenitentiae, ibid. (col. 2309, 1. 7); misericordia fructum non haberet (qu. 69); uberiorem fructum iustitiae (qu. 99).

Promptiores fierent circa bonos actus : prompti sint circa fidem (in Rom. iv I 7): circa haec peccata promptiores (in Rom. v I4); prompti sint circa obsequia dei (in Eph. vi Io); promptam . . c circa fidem (in Col. i 9); promptiores . . circa traditionem euangelicam (in Col. ii 5). Cf. nequis indiligens circa se (qu. 22 ; cf. qu. I15, col. 2354); neglegentes et inprouidi circa se (qu. 34 ); studiosi circa scripturas sacras (qu. $4^{6}$ ); circa curam animae neglegentes (qu. I 1o, col. 2332); cf. qu. I 15 (coil. 2358); sollicitus erat circa officium (in 2 Cor. vi 5 ), cet.

Actus: this, and not acta, is the regular form in our author, who uses gesta also, but hardly ever for the deeds of man.

Paenitere, personally used, is common to this author with other Latin Christian writers.

$A b$ errore cessare: $a b$ hac appellatione cessare deberent (qu. I 14, col. 2344, 29).

Interueniente mentis dolore: cf. interueniente causa neglegentiae uel erroris (in Gal. ii I I); nulla interueniente lamentatione paenitentiae (qu. 102, col. 2306, 29); interueniente gemitu et fletu (ibid. 35 ); interuentu paenitentiae (ibid. col. 2308, 29); interuentu misericordiae (qu. 105, col. 23 I 5,63 ), cet.

The length of this proof could easily be trebled, but it will, I hope, be regarded as sufficient.

Alex. Souter. 